\title{
A Phonological Study of the Influence of Arabic Stress on the Pronunciation of English Words by Saudi ESL Learners
}

\author{
Reem Maghrabi \\ Department of English - College of Languages and Translation - University of Jeddah \\ Jeddah- Saudi Arabia \\ Email: romaghrabi@uj.edu.sa
}

\begin{abstract}
Stress plays a profound role in languageintelligibility and comprehensibility. However, stress is considered a problematic area by ESL learners. Many studies have examined L2 acquisition of suprasegmmental elements such as pitch, tone and intonation, but few have focused on stress in relation to Arabic language transfer. For example, Guion(2003) has studies the influence of the factors of syllable structure and word class on stress assignment by ESL learners. Kelley (1992) has studied the influence of language stress properties on the second language acquisition of primary word stress. This paper investigates English word stresspronunciation errors by of Saudi learners of ESL. Itintends to examine the transference of Arabic on the learning of English word stress by Saudi learners of ESL.It explores the relation between language interference and stress assignmentin disyllable words(including compound words) and word-class pairs. It also examines if knowledge of noun/verb grammatical class could influence the production of stress. Moreover, it aims to explore thecorrelation between misplacement of stressand vowel change by Saudi ESL learners. Thirty three Saudi advanced learners of ESL participated in three experiments to produce 20 English disyllable words, 20 English compound words, and 20 English disyllabic word-class pairs. The errors in stress placement were inversely not proportional to the level of proficiency in English as students continued to incorrectly assign stress in disyllable words, compound words and word-class pairs. Most Saudi students placed initial stress on disyllabic words and final stress on compound words, a rule that is used with SA words. There is a correlation between stress misplacement and vowel change in disyllable words and word-class pairs but not in compound words. Errors occur more frequently with word-class pairs regardless of the students' knowledge of grammatical class stress assignment rules.
\end{abstract}

Keywords: Suprasegmental phonology, English and Arabic word stress, phonological transfer, word-class pairs. 


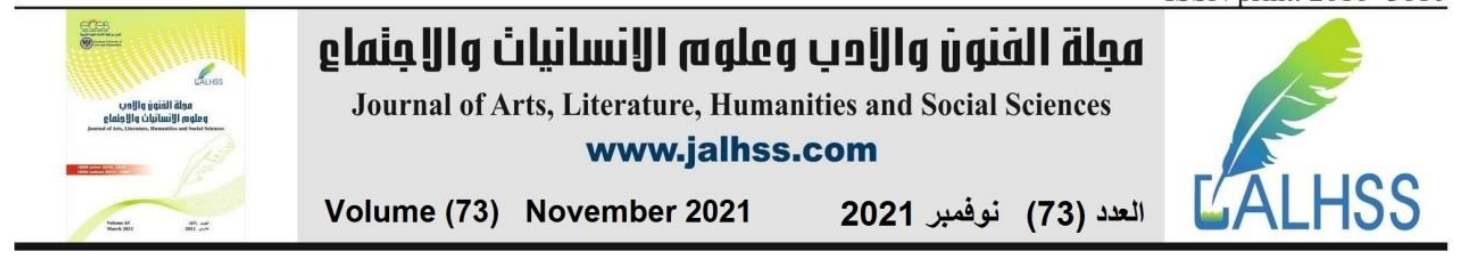

\section{Introduction}

Learning the sound structures of English by native speakers of Arabic is not an easy task especially when it comes to suprasegmental phonology.Many studies have examined the pronunciation errors made by second language learners, but not many have examined the effect of language interference on stress assignment.AlGhazali (1973), have proventhe interference from Arabic in the assignment of stress to English words. Another study by Bian (2013) has shown that Chinese EFL learners of English transferChinese stress to English words as both languages have different sound systems. in addition, Guion's (2003) examined three factors affecting speakers' stress placement (syllable structure, lexical class and phonologically similar words). He found that stress assignment was significantly influenced by syllable structure and the stress patterns of phonologically similar real words. On the other hand, some other studies like Bettiand Ulaiwi (2018) have hypothesized that there is no difference between English and Arabic in terms of degrees, types, and functions of stress. In both languages stress is connected with strong syllables. Other studies have proven evidence of transfer at phonology more than any other linguistic levels (Ellis, 1994). Also, pronunciation errors made by ESL could be reflections of sound inventory, rules of combining sounds, and the stress and intonation patterns of their native language (Swan \& Smith, 1987). (Choa, 1968) has argued that English and Arabic have many differences in their phonological systems. Even though short and long vowels exist in both languages, English long vowels are more in English compared to Arabic. Moreover, stress and intonation patterns are different. Consequently, Arabic learners of ESL often transfer their Arabic language rules into English especially at the level of phonology (Gui,1978). Therefore, it is necessary for Saudi teachers of ESL to realize the influence of Arabic on English pronunciation learning especially suprasegmental feature like stress to avoid phonological transfer(Archibald,1992). To learn the pronunciation of English words effectively, students need to be aware of the similarities and differences between English and Arabic sound system in application. This study aims to present the problematic factors that could account for stress misplacement in English words by Saudi ESL learners. In addition, it hopes to shed light on the importance of knowing the differences between Arabic and English word stress pronunciation rules in order to eliminate errors by Saudi ESL learners. By examining the production of stress in English disyllable words, compound words, and word-class pairs by Saudi ESL learners, English teachers could understand the reasons for pronunciation difficulties and means to avoid them.

\section{Literature review}

Word stress is a prosodic feature that many learners of ESL find difficult to pronounce. In Arabic, word stress is present but may have different rules of placement that could trigger transference errors when learning ESL. Roach (2009), identifies stress as syllable prominence. In other words, some syllables are pronounced with more prominence so that they stand out acoustically and perceptually. In addition, four parameters work in combination to identify stressed syllables. These are: 


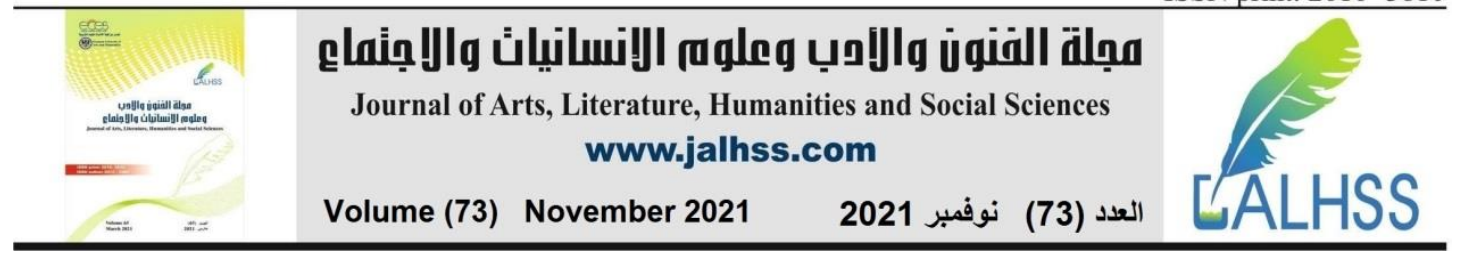

loudness, length, pitch and quality. Languages could be classified into predictable stress languages, in which stressed syllables are based on phonological characteristics, such as French, and non-predictable stress languages, in which primary stress is not fixed and placement of stress could result in different meanings or grammatical category, such as English (Altmann, 2006). Consequently, word stress acquisition could be difficult for ESL learners as they are insensitive to the syllabic structure of English words and word stress rules. Most of the studies on second language acquisition of English word stress have considered the effect of mother tongue language. Results have shown evidence of transfer of native language stress properties on the acquisition of second language word stress. Learners with predictable stress in their native language (e.g. Arabic), did poorly in perceiving the location of stress while their production was native like. On the contrary, learners with unpredictable stress in their native language (e.g. Chinese), performed well in perception and poorly in production of word stress. Chen(2008) has investigated the production and perception of English stress by Chinese learners and concluded that the main reason behind learners' failure to perceive and produce English word stress was negative transfer of mother tongue insensitivity to vowel length and overgeneralization of English word assignment rules. Language transfer is identified by Ellis (1994) as applying knowledge from a native language to a second language. In Odlin's (1989) perspective, language transfer is the influence resulting from the similarities and differences between the target language and any other language that has been acquired. Even though similarities between L1 and L2 could help in learning through positive transfer of the native language pattern, difficulties and errors could arise from negative transfer (Ellis, 1994). Many studies have given attention to the influence of language transfer at different linguistic levels such as phonological, lexical, syntactic and semantic. However, it would be difficult to decide at what level inhibits transfer more (Altmann, 2006). Also, many studies have given theoretical reasons for expecting the influence of the L1 to be more in pronunciation than in syntax. This could be due to the possibility that most learners have a highly developed awareness of grammatical properties than of phonological ones (Ellis, 1994). Research on second language acquisition has found that noun-verb difference is one of many phonological correlates to grammatical class that exists in English and other languages (Kelly, 1992). As phonology is arbitrarily related to semantic and syntactic properties, correlations between phonology and grammatical class vary arbitrarily from language to language, (Levy, 1983). Thus, to learn the English noun-verb stress difference, ESL learners should have knowledge of the noun-verb grammatical categories and actual perception of lexical stress in disyllabic words.Hypothetically, disyllabic English nouns tend to have stress on the first syllable (a trochaic pattern), whereas disyllable English verbs tend to have primary stress on the second syllable (an iambic patterns), (Sherman, 1975). Accordingly, the noun-verb stress difference is one of many phonological correlates to grammatical class that exists in English and other languages (Kelly, 1992). Therefore, nonnative speakers of English should be able to learn such relation and the acquisition of this knowledge should not depend on the age at which learning of the nonnative language began (Kelly \& Martin, 


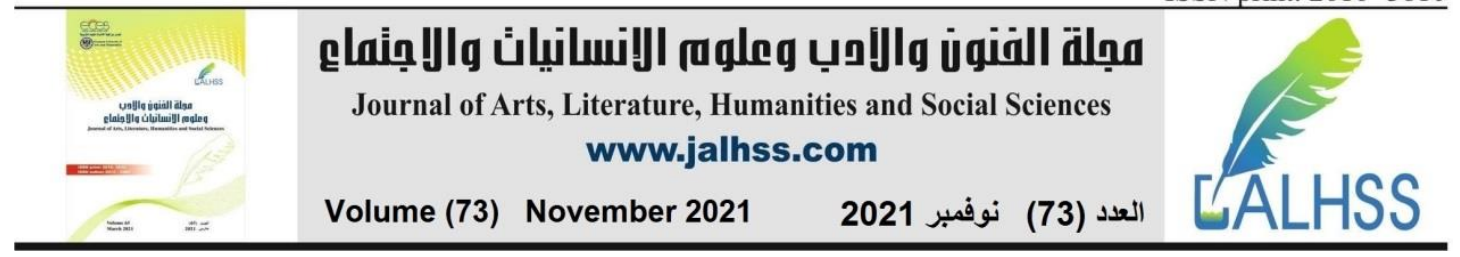

1994).Clak\&Yallo (1990) concluded in their study, however, that nonnative speakers find it easy to identify the stress pattern of disyllabic English words. They also found that nonnative speakers made more errors on iambic nouns and trochaic verbs than on trochaic nouns and iambic verbs. All in all, nouns were classified more accurately than verbs among nonnative speakers. In another study, Gleitman (1990) has argued that learners should have difficulty with phonology cues to grammatical class that involve phonemic distinctions, which are not present in their native language. This study intends to test whether Saudi ESL learners could distinguish the stress difference of noun-verb English disyllabic word-class pairs correctly and if the errors are less frequent compared to disyllabic words. It also examines if the Saudi learners' knowledge of phonological rules of noun-verb stress could decrease the frequency of stress errors. In addition, it aims to find out if stress is associated with language interference and vowel quality.

In English and Arabic stress means prominence. Stressed syllables are recognized as stressed because they are more prominent than other syllables (Roach, 2009). Also, stress refers to loudness that vowels or syllables carry in words in at least two degrees; strong or weak (primary or secondary) (Teschner\& Whitley,2004). Fry (1958) identifies stress as a result of interaction of pitch, intensity, and duration. However, in any language, speakers do not produce vowels with the same prominence. Stress usually is of two types, word stress, that occurs in the environment of isolated words including compounds, and sentence stress, that that occurs in connected speech. Although word stress is a complex matter, learning English general principlescould help in the pronunciationof English content words effectively (Li, 1999). The most common word type in English is two-syllable words with a strong initial syllable and a weak second syllable (Garlson, Elenius, Granstorm, \&Hunnicutt, 1985). In content words, stress is decided according to some factors e.g, if the word is simple or complex, if the word is a compound, to what grammatical category the word belongs to, the number of syllables of the word, and the phonological structure of the word. In English, syllables of long vowels carry the stress, and there are certain stress rules that determine the assignment of stress. For example, if a word (a noun or an adjective), stress is on the first syllable, while if it is a verb, stress is on the second syllable.In Arabic, syllable structure determines stress, as it is assigned by the nature of vowel. However, Arabic is a syllabic language, thus when a word consists of a sequence of syllables, the first syllable usually carries the primary stress. Another stress placement rule in Arabic says that when a word includes a long syllable (vowel) this syllable receives the primary stress. In addition, if a word consists of two long syllables or more, the syllable near the end of the word carries the primary stress. Betii\&Ulaiwi (2018) state that the main stress rules in Arabic are as follows: 1. Stress is on the first syllable, no matter what that first syllable is like (strong or weak). 2. Stress falls on the second syllable (the penult) if that syllable is strong (CVV). 3. If the second syllable of the word is weak (CV), stress is on the third syllable (the antepenult). 3. Stress falls on the last syllable in the case of stopping. In Arabic compound words, primary stress is assigned to the leftmost primary-stressed vowel in a noun, verb, or adjective.Furthermore, the 


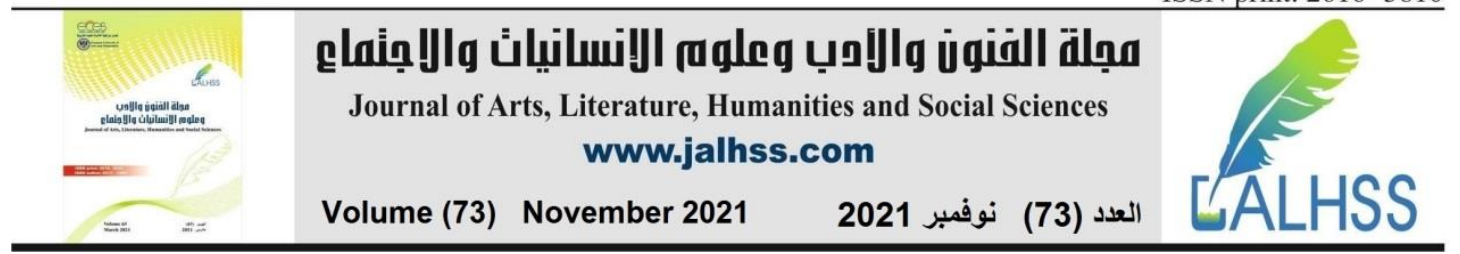

adjective carries the primary stress in noun-adjective phrases /fustanun'azraq/ (a blue dress). While, in the construct case, stress is on the second element, /kitabul'walad/ (the boy's book).Also, stress falls on the first element in additional structure /babul'madrasah/ ( the school door).

Contrastive analysis may not always predict the transfer errors learners make in actual learning contexts, but it cannot be denied that such interference exists and could cause difficulties for ESL (Whitman \& Jackson, 1972). Students learning ESL tend to use the Arabic word stress pattern that assigns primary stress on first syllables (Gazali, 1973). Therefore, learning English syllable stress is a bit challenging for Arabic students. Thus, contrastive analysis could be useful in predicting problematic areas of stress assignment as it shows how negative transfer could occur when Arabic learners of English produce English words.

\section{Objectives of the study}

1. To examine the effect of syllable structure and lexical class on stress assignment by Saudi learners of ESL

2. To investigate the interference of Arabic stresspattern on English word stress pronunciation

3. To examine the relationship between stress assignment of English word stressand vowel change by Saudi learners of ESL

4. To explore the effect of noun-verb stress assignment ruleson stress assignment by Saudi learners of ESL

\section{Methodology}

Thirty three advanced ESL Saudi learners from the University of Jeddah participated in the study. They are third year English major undergraduates who speak Arabic as a native language. These learners of ESL were chosen for this experiment as they have taken an introduction to English phonetics and phonology course and their basic knowledge on supra-segmental phonology was ensured, which was a prerequisite for the experiment. None of the students had prior information about the study under experiment. Three experiments were held. In the first one, twentydisyllable words of first/second syllable stress were selected from the study of Bian's (2013) to investigate the interference of Arabic stress patterns on Saudi ESL learners' first/second syllable word stress assignment. The twenty word are as follows:

(1) origin (2) forgot (3) unless (4) context (5) connect (6) obtain (7) effect (8) protect (9) congress (10) transcript (11) rotate (12)decade (13) forget (14) police (15) select (16) aspect (17) possess (18)recent (19)detect (20) product

Each subject was given the twenty words and was asked to read and record them after they were satisfactorily produced to be transcribed and analyzed using IPA.

The second experiment was held to investigate the interference of Arabic stress patterns on Saudi ESL learners' compound stress assignment. Twenty compound wordswere selected from the study of Bian's (2013) for this experiment. Some of 


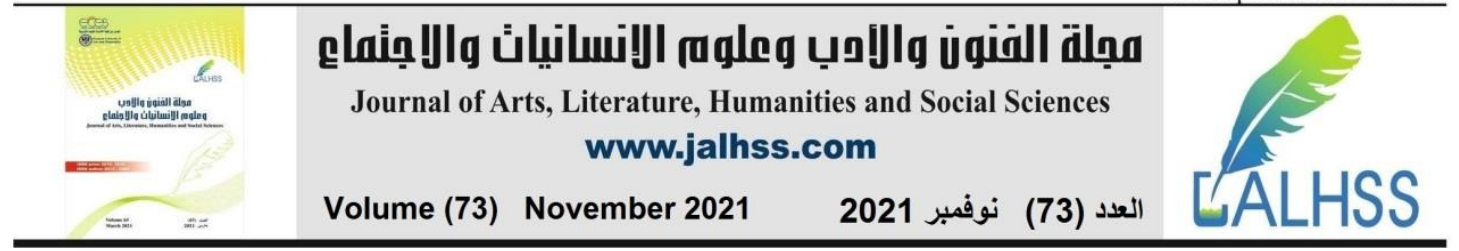

them have a primary stress on the first element and others have it on the second element. The subjects were asked to read and record the given compound words to be transcribed and analyzed by the examiner. These compound words are as follows:

(1) doorstep (2) loudspeaker (3) earthquake (4) hardworking (5) hairbrush

(6) homemade (7) drugstore (8) town hall (9) dining room (10) prime minister

(11) make-believe (12) old-fashioned (13) fountain pen (14) bad tempered

(15) fault finding (16) second-class (17) grandmother (18) suitcase (19) red herring (20) heart-shaped

In the third experiment, the students were asked to read and record twenty word-class pairs of disyllable words selected from Roach's (2009). The words' stress vary according to their $(\mathrm{N} / \mathrm{V})$ grammatical class. These word-class pairs are as follows:

(1) abstract (2) conduct (3) contract (4) contrast (5) desert (6) escort (7) export

(8) import (9) insult (10) object (11) perfect (12) permit (13) present (14) produce (15) protest (16) rebel (17) record (18) subject (19) suspect (20) increase

Student were shown the class of words they were asked to read and they were given the rules of stress placement of word-class pairs. These words were transcribed and analyzed to check if vowel change is correlated to stress misplacement and whether word-class knowledge has any effect on stress assignment.

\section{Results and discussion}

The three experiments (table.1) show the students' productions of stress in all the word structures under study. Word-class pairs seem to be the most problematic area where stress placement errors occur with $49 \%$ followed by disyllable words $30 \%$ and finally compound words $21 \%$.

Table 1. Total \% of word structure stress errors

\begin{tabular}{|l|l|l|}
\hline Word structure type & $\begin{array}{l}\text { Total no. of } \\
\text { errors }\end{array}$ & $\%$ \\
\hline Disyllable words & 294 & $30 \%$ \\
\hline Compound words & 205 & $21 \%$ \\
\hline Word-class pairs & 484 & $49 \%$ \\
\hline Total & \multicolumn{2}{|c|}{983} \\
\hline
\end{tabular}

Figure 1. \% of errors of all types of word structure

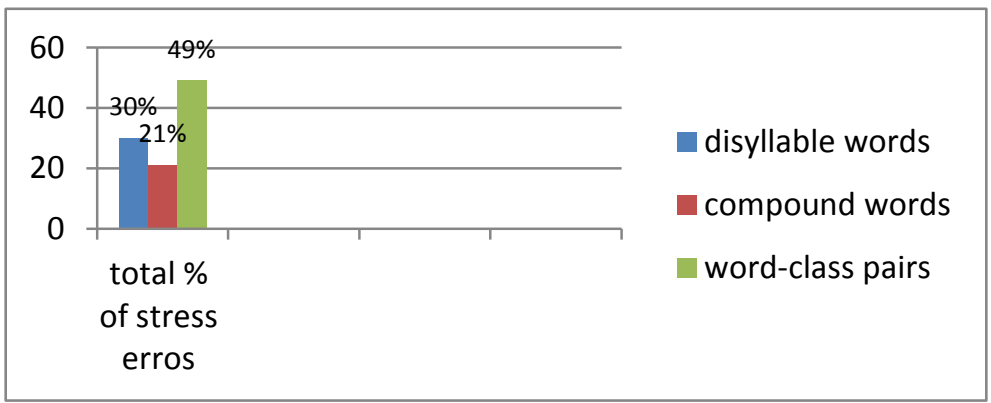




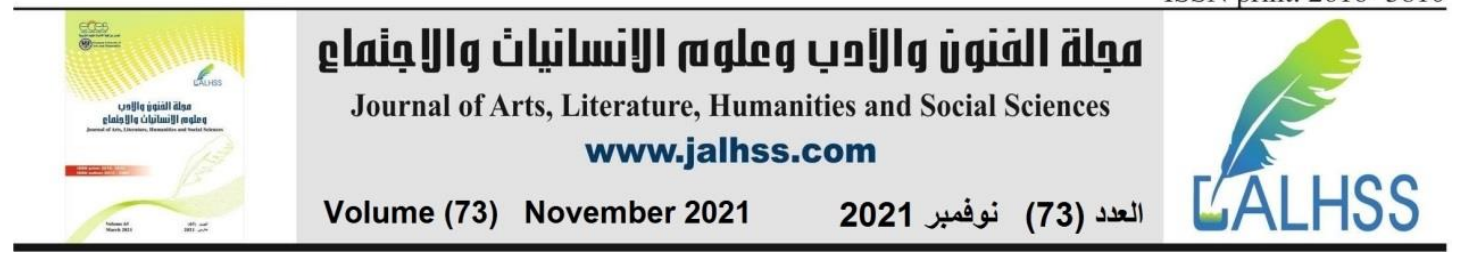

The results of experiment 1 , as shown in Table 1, show that the most frequent error in stress placement is in the word 'rotate' $8.8 \%$, followed by the word 'police' $8.5 \%$, and finally the word 'predict' $7.5 \%$. On the other hand, the least frequent error in stress placement occur in the words 'recent, product' $1.7 \%$, followed by the word 'aspect' $2 \%$, and finally the word 'detect' $2.4 \%$. Students had difficulties in placing stress on the right place in all the words. In most of the cases, subjects tended to misplace stress on the first syllable (e.g.'forget, 'unless, 'connect, 'obtain,) instead of the second syllable. By doing so, students may have followed the English rule which states that stress is associated with vowel quality. This means that if the vowel is weak, syllable stress is deleted or changed (Ladefoged (1982). This is evidenced by the change of vowels from weak to strong in order to shift the primary stress or by placing the stress on the strongest syllable perceived by students.

\subsection{Disyllable words}

In the first experiment, Subjects tend to use a strong-weak pattern in placing stress on words as most of the errors show (table. 2). By doing so, weak vowels are changed to be strong to cope with the stress shift. For example, [ə] changed into $\rightarrow[\mathrm{p}]$ and $[\Lambda]$ in the words 'possess, unless' due to misplacement of stress. In the words 'select, effect' [I] is changed into $\rightarrow$ [i:] so that the stress could move to the first syllable instead of being on the second syllable. Vowel change also happen in [ə] as it changed to $\rightarrow[0]$ and $[\mho]$ in the words 'obtain, police'. In Arabic, stress usually falls on the first syllable (Ulaiwi, 2018). It is likely that subjects apply this rule as they read the words and misplace the stress. On the other hand, the change of vowel quality could be triggered by the misplacement of stress and not the other way round. English is left-prominent for its metrical structure (Gui, 1978). Such a cross-linguistic difference in stress patters could result in Saudi learners' misplacement of word stress in English words as the examples in table.2 illustrate.Saudi learners of English frequently mispronounce English words by placing the primary stress on the first syllable instead of the second without considering the strong syllable that should likely carry the stress. Negative transference of Arabic stress is shown as primary stress falls on the first syllable in Arabic whether it is weak or strong (Ulaiwi, 2018).

Table 2. Total no. of disyllable word stress and vowel change

\begin{tabular}{|c|c|c|c|c|c|}
\hline Word & Target & $\begin{array}{l}\text { Errors of } \\
\text { stress } \\
\text { placement }\end{array}$ & $\begin{array}{l}\text { Vowel } \\
\text { change }\end{array}$ & $\begin{array}{l}\text { Total no. of } \\
\text { errors }\end{array}$ & $\%$ \\
\hline Origin & /'prədzən/ & /ə'ri:dzən/ & $\begin{array}{l}{[\mathrm{p}] \rightarrow[\mathrm{\partial}]} \\
{[ə] \rightarrow[\mathrm{I}:]}\end{array}$ & 14 & $4.8 \%$ \\
\hline Forget & /fa'get/ & /'fo:rget/ & {$[ə] \rightarrow[0:]$} & 20 & $6.8 \%$ \\
\hline Unless & /ən'les/ & /'Anles/ & {$[ə] \rightarrow[\Lambda]$} & 15 & $5.1 \%$ \\
\hline Context & /'kpntekst/ & /kən'tekst/ & {$[\mathrm{p}] \rightarrow[$ [ə] } & 11 & $3.7 \%$ \\
\hline Connect & /kə'nekt/ & /'konnekt/ & {$[ə] \rightarrow[0]$} & 17 & $5.8 \%$ \\
\hline Obtain & /əb'teIn/ & /'obtein/ & {$[\partial] \rightarrow[0]$} & 16 & $5.5 \%$ \\
\hline Effect & /I'fekt/ & /'i:fekt/ & {$[\mathrm{I}] \rightarrow[\mathrm{I}:]$} & 18 & $6.1 \%$ \\
\hline Protect & /pro'tekt/ & /prov'tekt/ & {$[ə] \rightarrow[\partial v]$} & 19 & $6.5 \%$ \\
\hline Congress & /'kpygres/ & /kəy'gres/ & {$[\mathrm{p}] \rightarrow[\mathrm{\partial}]$} & 11 & $3.7 \%$ \\
\hline Transcript & /'trænskript/ & /trən'skript/ & {$[æ] \rightarrow[\partial]$} & 20 & $6.8 \%$ \\
\hline
\end{tabular}




\begin{tabular}{|c|c|c|c|c|c|c|}
\hline \multirow{2}{*}{ 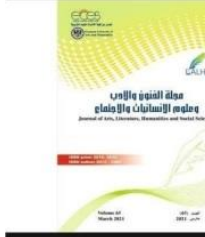 } & \multicolumn{6}{|c|}{ 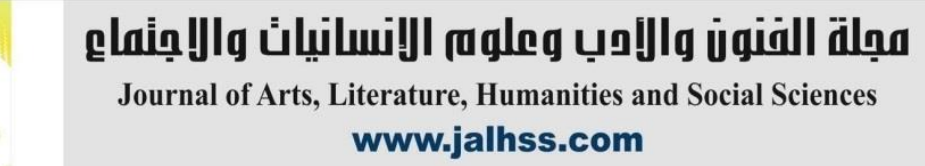 } \\
\hline & \multicolumn{2}{|c|}{ Volume (73) } & \multicolumn{2}{|c|}{ November 2021} & نوفمبر 2021 & العدد (73) \\
\hline Rotate & /rəo'teit/ & /'rot & ent/ & {$[\partial \mho] \rightarrow[\mho]$} & 26 & $8.8 \%$ \\
\hline Decade & /'dekerd/ & /d't' & eid/ & {$[\mathrm{e}] \rightarrow[\mathrm{I}]$} & 10 & $3.5 \%$ \\
\hline Predict & /pri'dikt/ & /'pri & dikt/ & {$[\mathrm{I}] \rightarrow[\mathrm{I}:]$} & 22 & $7.5 \%$ \\
\hline Police & /pə'li:s/ & /'po & li:s/ & {$[\partial] \rightarrow[\mho]$} & 25 & $8.5 \%$ \\
\hline Select & /sı'lekt/ & /'si: & ekt/ & {$[\mathrm{I}] \rightarrow[\mathrm{I}:]$} & 12 & $4 \%$ \\
\hline Aspect & /'æspekt/ & /a's & ekt// & {$[æ] \rightarrow[\partial]$} & 6 & $2 \%$ \\
\hline Possess & /po'zes/ & /'pp & zes/ & {$[\partial] \rightarrow[\mathrm{p}]$} & 15 & $5.1 \%$ \\
\hline Recent & /'ri:snt/ & /ri's & ent/ & {$[\mathrm{i}:] \rightarrow[\mathrm{I}]$} & 5 & $1.7 \%$ \\
\hline Detect & /'ditekt/ & /di: & tekt/ & {$[\mathrm{I}] \rightarrow[\mathrm{I}:]$} & 7 & $2.4 \%$ \\
\hline Product & /'prodəkt/ & /prn & $\mathrm{d} \Lambda \mathrm{kt} /$ & {$[\partial] \rightarrow[\mathrm{p}]$} & 5 & $1.7 \%$ \\
\hline Total & & & & & 294 & $100 \%$ \\
\hline
\end{tabular}

Table 3. 1st $\rightarrow$ 2nd \& 2 nd $\rightarrow$ 1st disyllable word stress placement errors

\begin{tabular}{|c|c|c|c|c|c|c|c|c|c|c|c|}
\hline \multicolumn{6}{|c|}{1 st $\rightarrow$ 2nd disyllable word stress placement errors } & \multicolumn{6}{|c|}{2 nd $\rightarrow 1$ st disyllable word stress placement errors } \\
\hline Word & Target & $\begin{array}{l}\text { Errors of } \\
\text { stress } \\
\text { placement } \\
1 \text { st } \rightarrow 2 \text { nd }\end{array}$ & $\begin{array}{l}\text { Vowel } \\
\text { change }\end{array}$ & $\begin{array}{l}\text { Total } \\
\text { no. of } \\
\text { errors }\end{array}$ & $\%$ & Word & Target & $\begin{array}{l}\text { Errors of } \\
\text { stress } \\
\text { placement } \\
2 \text { nd } \rightarrow 1 \text { st }\end{array}$ & $\begin{array}{l}\text { Vowel } \\
\text { change }\end{array}$ & $\begin{array}{l}\text { Tota } \\
1 \text { no. } \\
\text { of } \\
\text { error } \\
\mathrm{s}\end{array}$ & $\%$ \\
\hline Origin & /'prədzən/ & /ə'ri:dzən/ & $\begin{array}{l}{[\mathrm{p}] \rightarrow[]} \\
{[ə] \rightarrow[\mathrm{I}:]}\end{array}$ & 14 & $20.2 \%$ & Forgt & /fə'get/ & /'fo:rget/ & {$[ə] \rightarrow[\supset:]$} & 20 & $8.9 \%$ \\
\hline Context & /'kpntekst/ & /kən'tekst/ & {$[\mathrm{p}] \rightarrow[\partial]$} & 11 & $16 \%$ & Unless & /ən'les/ & 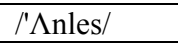 & {$[ə] \rightarrow[\Lambda]$} & 15 & $6.7 \%$ \\
\hline Congress & /'kpygres/ & /kəך'gres/ & {$[\mathrm{p}] \rightarrow[\partial]$} & 11 & $16 \%$ & Connect & /ko'nekt/ & /'konnekt/ & {$[\partial] \rightarrow[0]$} & 17 & $7.5 \%$ \\
\hline Decade & /'dekeıd/ & /di'keıd/ & {$[\mathrm{e}] \rightarrow[\mathrm{I}]$} & 10 & $14.5 \%$ & Obtain & /ob'tein/ & /'obtein/ & {$[\partial] \rightarrow[0]$} & 16 & $7.1 \%$ \\
\hline Aspect & /'æspekt/ & /o'spekt/ & {$[æ] \rightarrow[ə]$} & 6 & $9 \%$ & Effect & /I'fekt/ & /'i:fekt/ & {$[\mathrm{I}] \rightarrow[\mathrm{I}:]$} & 18 & $8 \%$ \\
\hline Recent & /'ri:snt/ & /ri'sent/ & {$[\mathrm{i}:] \rightarrow[\mathrm{I}]$} & 5 & $7.2 \%$ & Protect & /pra'tekt/ & /pro't3kt/ & {$[\partial] \rightarrow[3]$} & 19 & $8.5 \%$ \\
\hline Detect & /'ditekt/ & /di:'tekt/ & {$[\mathrm{I}] \rightarrow[\mathrm{I}:]$} & 7 & $10.1 \%$ & Transcribe & /'trænskræib/ & /trən'skræib/ & {$[æ] \rightarrow[ə]$} & 20 & $8.9 \%$ \\
\hline \multirow[t]{5}{*}{ Product } & /'prodəkt/ & /pro'd $\Lambda \mathrm{kt} /$ & {$[\partial] \rightarrow[\mathrm{p}]$} & 5 & $7.2 \%$ & Rotate & /rəu'teIt/ & /'rv:tert/ & {$[\partial v] \rightarrow[\mho:]$} & 26 & $11.5 \%$ \\
\hline & & & & & & Predict & /pri'dıkt/ & /'pri:dıkt/ & {$[\mathrm{I}] \rightarrow[\mathrm{I}:]$} & 22 & $9.8 \%$ \\
\hline & & & & & & Police & /pə'li:s/ & /'poli:s/ & {$[\partial] \rightarrow[\mho]$} & 25 & $11.1 \%$ \\
\hline & & & & & & Select & /si'lekt/ & /'si:lekt/ & {$[\mathrm{I}] \rightarrow[\mathrm{I}:]$} & 12 & $5.3 \%$ \\
\hline & & & & & & Possess & /po'zes/ & /'ppzes/ & {$[\partial] \rightarrow[\mathrm{p}]$} & 15 & $6.7 \%$ \\
\hline Total & & & & 69 & $23.5 \%$ & Total & & & & 225 & $76.5 \%$ \\
\hline $\begin{array}{l}\text { Total no. } \\
\text { of errors \% }\end{array}$ & & & & & & & & & & & \\
\hline
\end{tabular}

The above table illustrates two kinds of stress misplacement errors of disyllabic words. It shows that students tended to move stress from the second syllable to the first syllable more frequently $76.5 \%$ than from the first syllable to the second $23.5 \%$. In other words, they used the strong-weak pattern and thus weak vowels in the first syllable change to strong ones. These words were perceived by the subjects as ending in a light syllable CVC which stresses the penultimate syllable according to SA stress rules. There is a strong correlation between disyllable stress misplacement and vowel change. Misplacement of stress triggers vowel change from weak o strong as the examples in the above table show. This could be an indication of the students' awareness of the stress rule in English as it falls onstrong syllables. However, the interference of Arabic stress rule where stress is usually placed on the first syllable in disyllabic words tends to be case. 


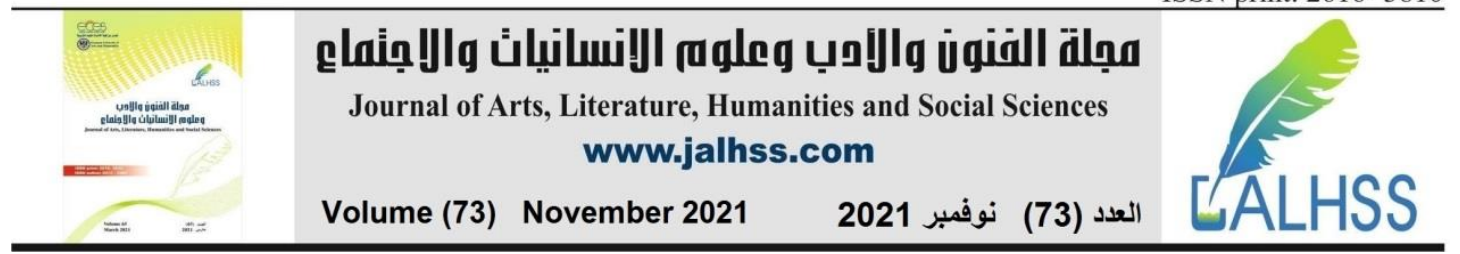

Table 4. Total \% of disyllable word stress errors

\begin{tabular}{|l|l|l|}
\hline $\begin{array}{l}\text { Disyllable word } \\
\text { stress error }\end{array}$ & No of errors & $\%$ \\
\hline 1 st $\rightarrow 2$ snd & 69 & $23.5 \%$ \\
\hline 2 nd $\rightarrow 1$ st & 225 & $76.5 \%$ \\
\hline Total & 249 & $100 \%$ \\
\hline
\end{tabular}

Figure 2. Total percentage of disyllable word stress errors

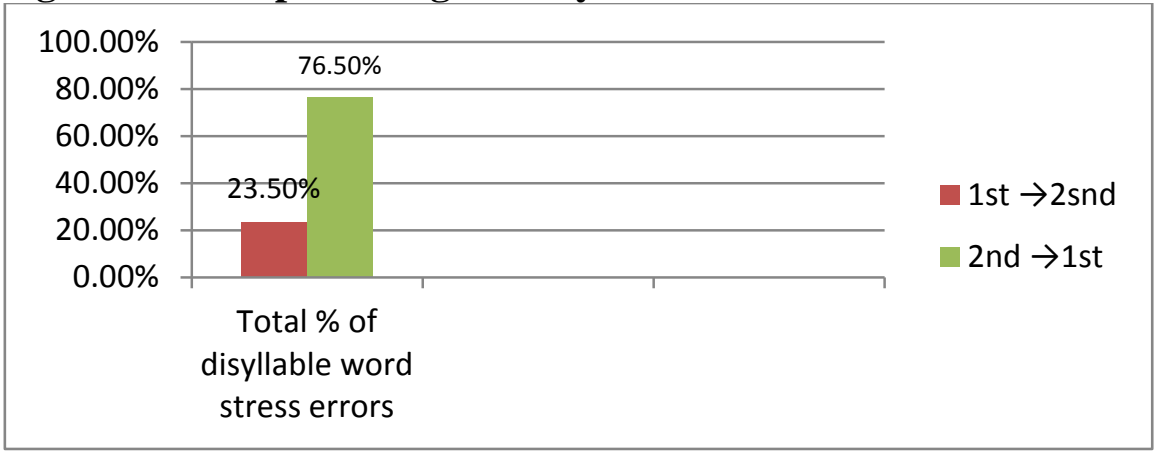

\subsection{Compound words}

Examining compound words, it is found that students transfer the Arabic rule of stress by placing stress on the second element without considering the compound rule in English where stress falls on the first element in (noun+ noun) compound words and on second element elsewhere. This could be an interference of the Arabic rule of addition (Ulaiwi. 2018), where stress falls on the second element. In compound words, errors occur more frequently with first stressed element words than with second stressed element words. Saudi students tend to use the weak-strong pattern instead of the strong-weakpattern in English compounds. Hence, instead of producing the correct stress form for the English compounds 'doorstep, 'earthquake, 'hairbrush, 'drugstore, 'dining room, 'make believe, 'fountain pen, 'fault finding, 'grandmother, 'suitcase, students tend to shift the primary stress to the second syllable.

Table 5. Total no. of compound stress placement errors

\begin{tabular}{|l|l|l|l|l|}
\hline Word & Target & $\begin{array}{l}\text { Errors of stress } \\
\text { placement }\end{array}$ & No. of errors & $\%$ \\
\hline Doorstep & 'Doorstep & Door'step & 10 & $4.9 \%$ \\
\hline Loudspeaker & Loud'speaker & 'Loudspeaker & 6 & $3 \%$ \\
\hline Earthquake & 'Earthquake & Earth'quake & 18 & $8.9 \%$ \\
\hline Hardworking & Hard'working & 'Hardworking & 9 & $4.4 \%$ \\
\hline Hairbrush & 'Hairbrush & Hair'brush & 12 & $5.9 \%$ \\
\hline Homemade & Home'made & 'Homemade & 7 & $3.4 \%$ \\
\hline Drugstore & 'Drugstore & Drug'store & 13 & $6.3 \%$ \\
\hline Town hall & Town 'hall & 'Town hall & 5 & $2.3 \%$ \\
\hline Dining room & 'Dining room & Dining 'room & 11 & $5.4 \%$ \\
\hline Prime minister & Prime 'minister & 'Prime minister & 7 & $3.4 \%$ \\
\hline Make-believe & 'Make-believe & Make-'believe & 11 & $5.4 \%$ \\
\hline Old-fashioned & Old-'fashioned & 'Old-fashioned & 6 & $3 \%$ \\
\hline Fountain pen & 'Fountain pen & Fountain 'pen & 12 & $5.9 \%$ \\
\hline
\end{tabular}




\begin{tabular}{|c|c|c|c|c|}
\hline \multirow{2}{*}{ 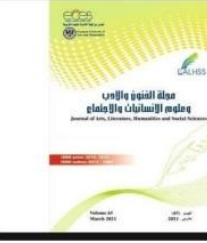 } & \multicolumn{3}{|c|}{ 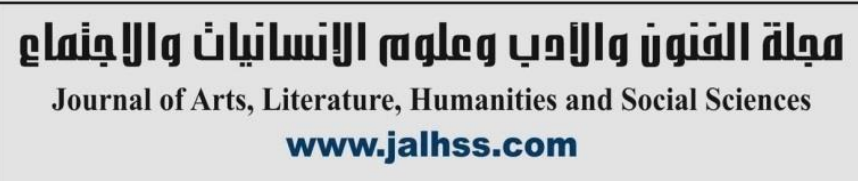 } & \\
\hline & Volume (73) & November 2021 & العدد (73) نوفمبر 2021 & \\
\hline Bad-tempered & Bad-'tempered & 'Bad-tempered & 9 & $4.4 \%$ \\
\hline Fault finding & 'Fault finding & Fault 'finding & 13 & $6.3 \%$ \\
\hline Second-class & Second-'class & 'Second-class & 7 & $3.4 \%$ \\
\hline Grandmother & 'Grandmother & Grand'mother & 10 & $4.9 \%$ \\
\hline Suitcase & 'Suitcase & Suit'case & 23 & $11 \%$ \\
\hline Red herring & Red 'herring & 'Red herring & 7 & $3.4 \%$ \\
\hline Heart-shaped & 'Heart-shaped & Heart-'shaped & 9 & $4.4 \%$ \\
\hline Total & & & 205 & $100 \%$ \\
\hline
\end{tabular}

Table 6. Total no. of 1 st $\rightarrow 2$ snd $\&$ 2nd $\rightarrow 1$ st stress placement errors in compound words

\begin{tabular}{|c|c|c|c|c|c|c|c|c|c|}
\hline Word & Target & $\begin{array}{l}\text { Errors of } \\
\text { stress } \\
\text { placement } \\
1 \text { st } \rightarrow 2 \text { snd } \\
\end{array}$ & $\begin{array}{l}\text { No. of } \\
\text { errors }\end{array}$ & $\%$ & Word & Target & $\begin{array}{l}\text { Errors of stress } \\
\text { placement } \\
2 \text { nd } \rightarrow 1 \text { st }\end{array}$ & $\begin{array}{l}\text { No. } \\
\text { of } \\
\text { error } \\
\text { s } \\
\end{array}$ & $\%$ \\
\hline Doorstep & 'Doorstep & Door'step & 10 & $7 \%$ & Loudspeaker & Loud'speaker & 'Loudspeaker & 6 & $9.5 \%$ \\
\hline Earthquake & 'Earthquake & Earth'quake & 18 & $12.7 \%$ & Hardworking & Hard'working & 'Hardworking & 9 & $14.3 \%$ \\
\hline Hairbrush & 'Hairbrush & Hair'brush & 12 & $8.5 \%$ & Homemade & Home'made & 'Homemade & 7 & $11.1 \%$ \\
\hline Drugstore & 'Drugstore & Drug'store & 13 & $9.2 \%$ & Town hall & Town 'hall & 'Town hall & 5 & \\
\hline Dining room & 'Dining room & Dining 'room & 11 & $7.7 \%$ & Prime minister & Prime 'minister & 'Prime minister & 7 & $11.1 \%$ \\
\hline Make-believe & 'Make-believe & Make-'believe & 11 & $7.7 \%$ & Old-fashioned & Old-'fashioned & 'Old-fashioned & 6 & $9.5 \%$ \\
\hline Fountain pen & 'Fountain pen & Fountain 'pen & 12 & $8.5 \%$ & Bad-tempered & Bad-'tempered & 'Bad-tempered & 9 & $14.3 \%$ \\
\hline Fault finding & 'Fault finding & Fault 'finding & 13 & $9.2 \%$ & Second-class & Second-'class & 'Second-class & 7 & $11.1 \%$ \\
\hline Grandmother & 'Grandmother & Grand 'mother & 10 & $7 \%$ & Red herring & Red 'herring & 'Red herring & 7 & $11.1 \%$ \\
\hline Suitcase & 'Suitcase & Suit 'case & 23 & $16.2 \%$ & & & & & \\
\hline Heart-shaped & 'Heart-shaped & Heart-'shaped & 9 & $6.3 \%$ & & & & & \\
\hline Total & & & 142 & $69 \%$ & & & & 63 & $31 \%$ \\
\hline $\begin{array}{l}\text { Total no. of } \\
\text { errors }\end{array}$ & & & & & & & & & \\
\hline
\end{tabular}

As students use the weak-strong pattern instead of the strong-weak pattern in English more frequently, it could be interpreted the role of language interference from the native language in the foreign language at a suprasegmental level maysuggest that contrastive analysis is a useful tool in studying the difficulties encountered in the learning process. However, examining the vowel change process while pronouncing compound words, it is found that there is no clear correlation between vowel change and stress misplacement. Students' errors did not trigger vowel change as there were no errors in the pronunciation of vowels.

Table 7. Total \% of compound word stress errors

\begin{tabular}{|l|l|l|}
\hline $\begin{array}{l}\text { Compound word } \\
\text { stress error }\end{array}$ & No of errors & $\%$ \\
\hline 1 st $\rightarrow 2$ snd & 142 & $69 \%$ \\
\hline 2 nd $\rightarrow 1$ st & 63 & $31 \%$ \\
\hline Total & 205 & $100 \%$ \\
\hline
\end{tabular}




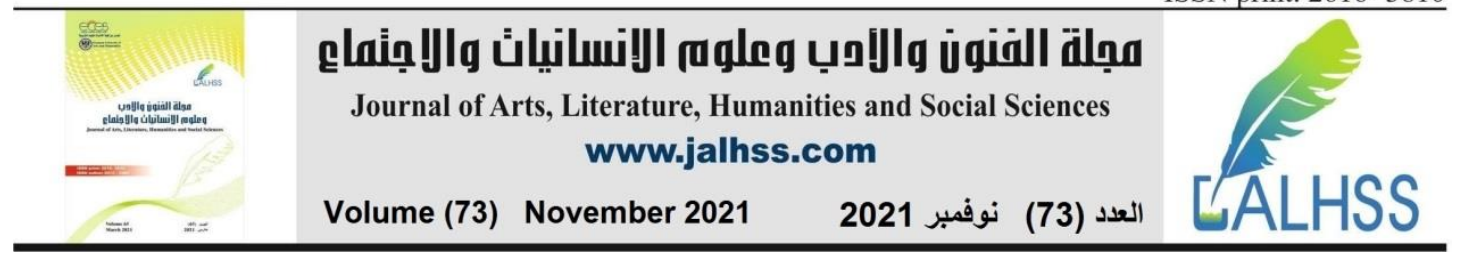

Figure 3. Compound word stress placement errors

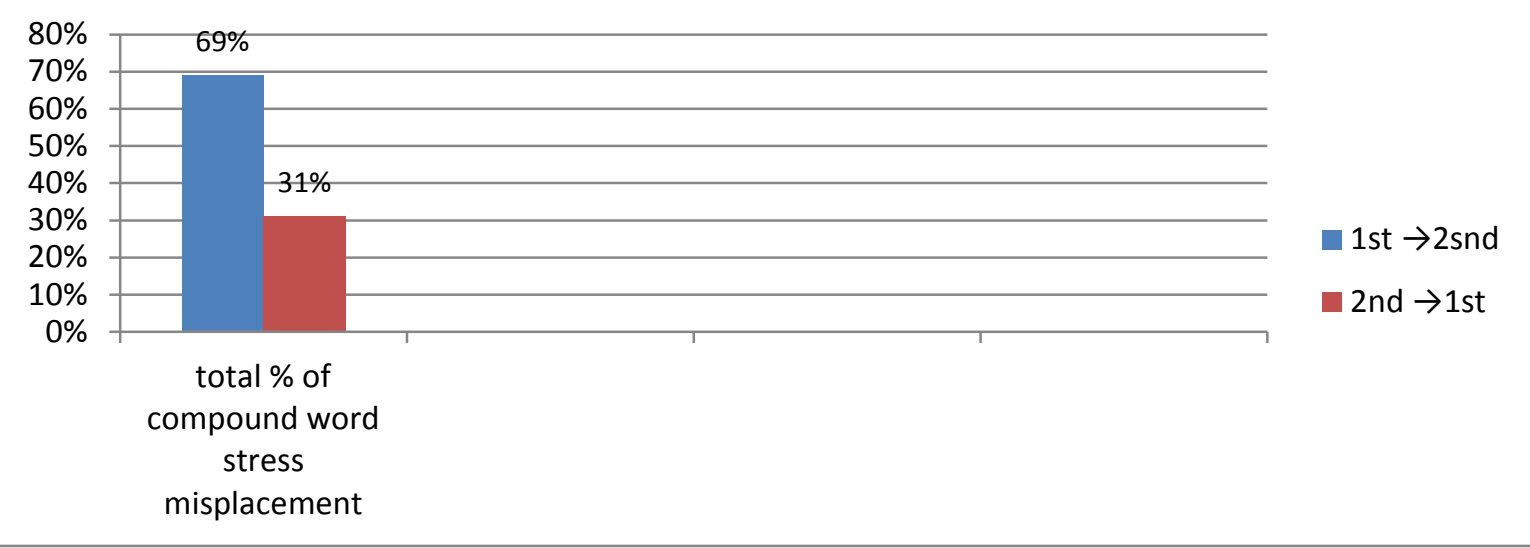

\subsection{Word-class pairs}

In this study, it is found that word-class pairs trigger more error occurrences. These words are identical in number of syllables and in phonemes, the only difference is in the grammatical class which controls stress change (Roach, 2009). Students were given the grammatical category before pronouncing them,yet they misplaced stress most of the time. Stress is changed from first to second syllable 69\% and changed from second to first syllable $31 \%$. This could indicate that the more students are aware of the stress rule, the more errors are produced. In other words, conscious awareness of stress rule may trigger unconscious stress errors. Therefore, as Bahrick\& Berger (1994) suggest, general properties of learning and memory, rather than language-specific operations, should be involved in learning the associations between sound and meaning that characterize the lexicon.

Table 8. Word-class pairs stress placement errors and vowel change

\begin{tabular}{|c|c|c|c|c|c|c|c|c|c|c|}
\hline Word & \begin{tabular}{|l|} 
Target \\
(A/N)
\end{tabular} & Error & $\begin{array}{l}\text { Vowel } \\
\text { change }\end{array}$ & $\begin{array}{l}\text { No. of } \\
\text { errors }\end{array}$ & $\%$ & $\begin{array}{l}\text { Target } \\
\text { (V) }\end{array}$ & Error & $\begin{array}{l}\text { Vowel } \\
\text { change }\end{array}$ & $\begin{array}{l}\text { No. of } \\
\text { errors }\end{array}$ & \\
\hline Abstract & /'æbstrækt/ & / $/ \Lambda$ b'strækt/ & {$[æ] \rightarrow[\Lambda]$} & 29 & $8 \%$ & /æb'strækt/ & 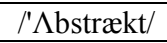 & {$[æ] \rightarrow[\Lambda]$} & 5 & $4 \%$ \\
\hline Conduct & /'kpnd $\Lambda \mathrm{kt} /$ & $/ \mathrm{kbn}$ 'd $\Lambda \mathrm{kt} /$ & ----- & 22 & $6.1 \%$ & /kən'd $\Lambda \mathrm{kt} /$ & /'kpnd $\Lambda \mathrm{kt} /$ & {$[\partial] \rightarrow[\mathrm{p}]$} & 4 & $3 \%$ \\
\hline Contract & /'kpntrækt/ & /knn'trækt/ & ----- & 15 & $4.2 \%$ & /kən'trækt/ & /'kpntrækt/ & {$[\partial] \rightarrow[\mathrm{p}]$} & 4 & $3 \%$ \\
\hline Contrast & /'kpntra:st/ & /knnt'ra:st/ & ------ & 16 & $4.5 \%$ & /kənt'ra:st/ & /'kpntra:st/ & {$[\partial] \rightarrow[\mathrm{p}]$} & 6 & $5 \%$ \\
\hline Desert & /'dezət/ & /de'zz:t/ & {$[$ [ə] $\rightarrow[3:]$} & 11 & $3.1 \%$ & /dı'zz:t/ & /'dezət/ & $\begin{array}{l}{[\mathrm{I}] \rightarrow[\mathrm{e}]} \\
{[3:] \rightarrow[\mathrm{\partial}]}\end{array}$ & 7 & $5.5 \%$ \\
\hline Escort & /'esko:t/ & /es'ko:t/ & ------ & 19 & $5.5 \%$ & /I'sko:t/ & /'esko:t/ & {$[\mathrm{I}] \rightarrow[\mathrm{e}]$} & 8 & $6 \%$ \\
\hline Export & /'ekspo:t/ & /ek'spo:t/ & ----- & 17 & $5 \%$ & / Ik'spo:t / & /'ekspo:t/ & {$[\mathrm{I}] \rightarrow[\mathrm{e}]$} & 5 & $4 \%$ \\
\hline Import & /'Impo:t/ & /Im'po:t/ & ----- & 20 & $5.6 \%$ & /Im'po:t/ & /'impo:t/ & & 5 & $4 \%$ \\
\hline Insult & /'Ins $\Lambda$ lt/ & /in's $\Lambda \mathrm{lt} /$ & ------ & 27 & $7.5 \%$ & /in's $\Lambda \mathrm{lt} /$ & /'ins $\Lambda$ lt/ & & 4 & $3 \%$ \\
\hline Object & /'pbdzekt// & /pb'dzekt/ & ------ & 5 & $1.4 \%$ & /əb'dzekt/ & /'pbdzekt/ & {$[\partial] \rightarrow[\mathrm{p}]$} & 9 & $7 \%$ \\
\hline Perfect & /'p3:frkt/ & /p3:'frkt/ & ------ & 6 & $1.6 \%$ & /pə'fəkt/ & /'p3:frkt/ & $\begin{array}{l}{[\partial] \rightarrow[3:]} \\
{[ə] \rightarrow[\mathrm{I}]}\end{array}$ & 15 & $12 \%$ \\
\hline Permit & /'p3:mit/ & /p3:'mit/ & ------ & 11 & $3.1 \%$ & /po'mit/ & /'p3:mit/ & {$[$ [ə] $\rightarrow[3:]$} & 6 & $5 \%$ \\
\hline Present & /'prezṇt/ & /pre'zṇt/ & ----- & 8 & $2.2 \%$ & /pri'zent/ & /'prezṇt/ & {$[\mathrm{I}] \rightarrow[\mathrm{e}]$} & 9 & $7 \%$ \\
\hline Produce & /'prodju:s/ & /prə'dju:s/ & {$[\mathrm{p}] \rightarrow[$ əอ] } & 33 & $9 \%$ & /prə'dju:s/ & /'prodju:s/ & {$[\partial] \rightarrow[\mathrm{p}]$} & 6 & $5 \%$ \\
\hline
\end{tabular}




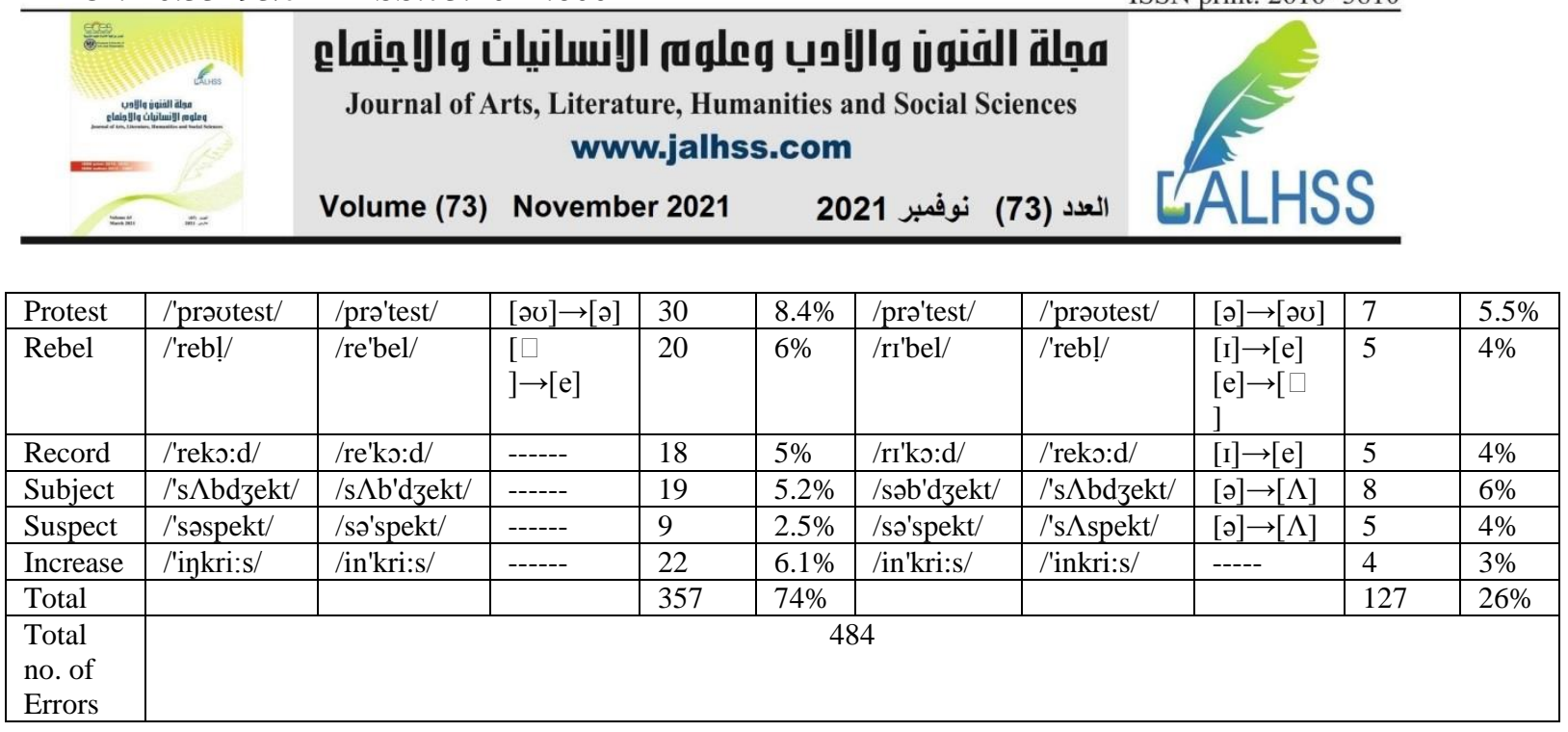

The word-class pair category was examined to find out if students were able to pronounce them more correctly as they were aware of the phonological-grammatical rule that places stress on first syllable in nouns and second syllable in verbs. It also examined if any vowel change was involved in the change of word stress compared to disyllabic words pronounced in experiment two. The above table shows that students seem to have difficulties producing noun word-class pairs $74 \%$ more than verb word class-pairs $26 \%$. The common pattern used by students was the weak-strong pattern. Contrarily, students use the strong-weak pattern in the first experiment when they produced disyllable words. Stress misplacement does not seem to trigger vowel change in the noun category (only five examples of vowel change), which could be an indication of the awareness of stress error production by students compared to the verb category (19 examples of vowel change).

Table 9. \% word-class pairs errors

\begin{tabular}{|l|l|l|}
\hline Word-class & No of errors & $\%$ \\
\hline A/N & 357 & $74 \%$ \\
\hline V & 127 & $26 \%$ \\
\hline Total & 484 & $100 \%$ \\
\hline
\end{tabular}

Figure 4. \% word-class pairs stress placement errors

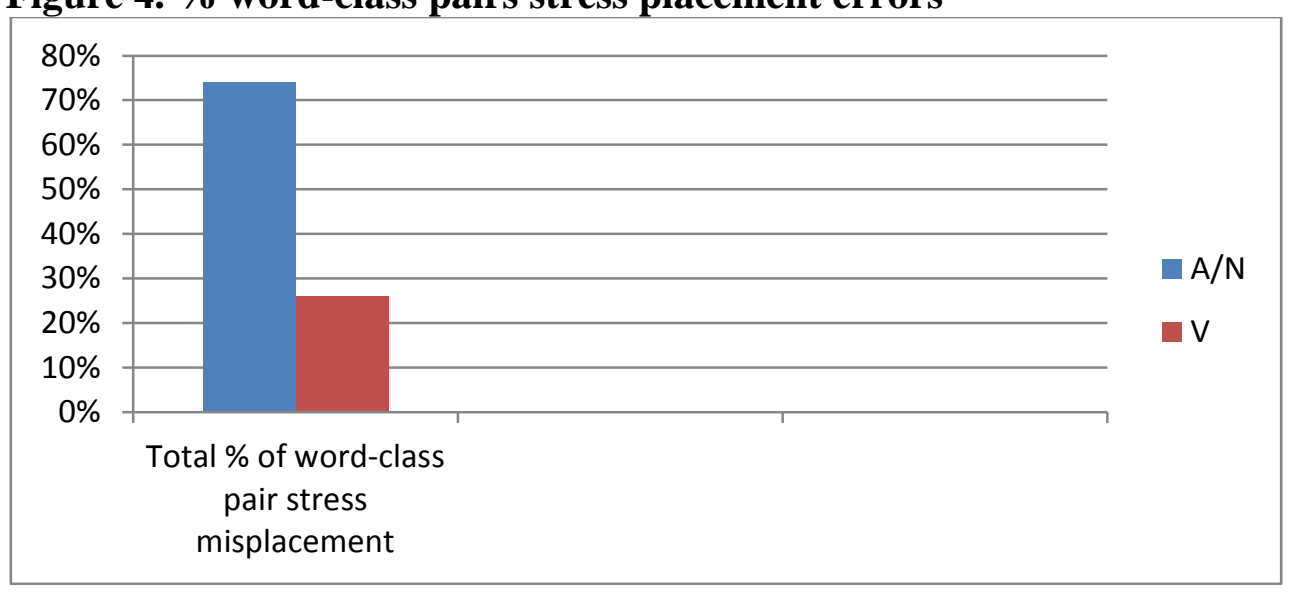

In word-class pairs, stress errors occur more frequently with disyllabic English nouns compared to disyllabic English verbs. In other words, errors occurred mostly in 


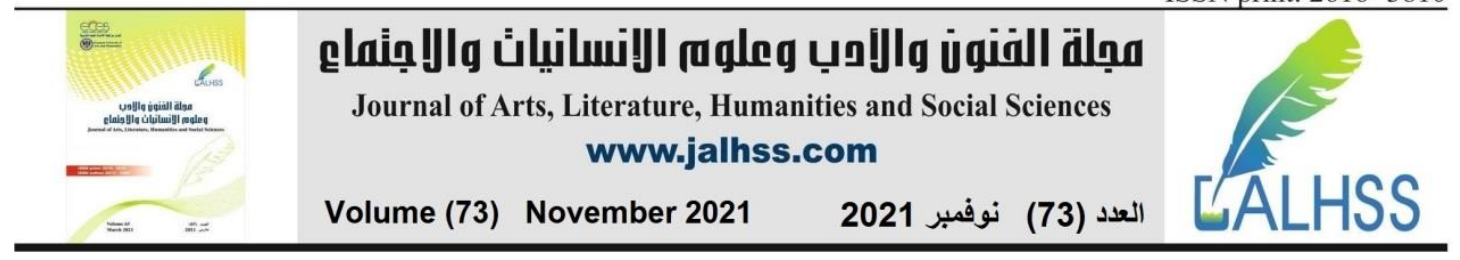

trochaic pattern compared to the iambic pattern. A close examination of the errors in disyllabic nouns reveals that there were some words that triggered stress errors more that the others. For example, the nouns 'produce' $9 \%$, followed by 'protest' $8.4 \%$, followed by 'abstract' $8 \%$, trigger vowel change. While the least frequent occurrences of stress errors were found in the nouns: ' object' $1.4 \%$, perfect' $1.6 \%$, and 'suspect' $2.5 \%$. On the other hand, students pronounced verbs more correctly compared to nouns. This may show that language transference dose not play a big role in stress misplacement compared with experiments one and two, where disyllabic word stress and compound word stress were examined. A close look at vowel change in relation to stress misplacement, it was found that vowel change happens but it does not affect the misplacement of stress. Although stress shifts from first syllable to second syllable more frequently with disyllable nouns, vowel change occurs less compared to verb production. For example, in the disyllabic word,/'æbstrækt/, [æ] changes into $[\Lambda]$ / $\Lambda$ b'strækt/. Similarly, in /'dezət/, [ə] changes into [3:], in /'prəvtest/ [əひ] changes to [ə], and in /'rebl]/ [ $\square$ ] changes to [e].However, in disyllabic verbs, vowel changes with every misplacement of stress. For example, in the verb /æb'strækt/, [æ] changes to $[\Lambda]$ when stress is misplaced on the first syllable /' $\Lambda$ bstrækt/ . Also, [ə] changes into [p] in /kən'd $\Lambda \mathrm{kt} /$, /kən'trækt/, /kənt'ra:st/, /əb'dzekt/, /prə'dju:s/. Additionally, [I] changes to [e] in /dr'zz:t/, /pri'zent/, /ri'bel/, and /ri'ko:d/. Sometimes, change occurs on more than one vowel in the same word, for example, in /pə'fəkt/, [ə] changes to [3:] in the first syllable and to [I] in the second. Also, in /dr'zz:t/, [I] changes to [e] in the first syllable, and [3:] changes to [ə] in the second.

\section{Implications for teaching English stress}

Cook (1996) states that in order to learn the pronunciation of a second language, new pronunciation habits should be acquired instead of relying on the first language rules.Although a broad definition of pronunciation includes both features as integral parts of spoken language (Bian, 2013), less attention is given to suprasegmental features of English when teaching it to learners and much focus is given to segmental features.This is because English teachers may assume that learning and pronouncing English phonemes correctly enables them to pronounce words fluently.However, being aware of the phonological differences between L1 and L1 could be more useful to avoid pronunciation errors. Further experiments should be carried in order to learn more about the challenges facing learners of English pronunciation. Teachers may be unaware of the suprasegmental features and, thus, lack confidence to teach them. Therefore, stress rules should have proficient pronunciation teachers of English to help students learn them (Kenworthey, 1987). The use of a communicative approach in language teaching motivates pronunciation improvement. Communicative teaching methods could help students perceive and produce English sounds and words correctly (Coniam, 2002). Research on EFL learners' pronunciation attitudes towards suprasegmental features such as stress, has shown that using audio-visual software has helped and encouraged learners of English to become more aware of their own pronunciation inside and outside classroom. Learners of Englishare advised to learn word stress with other skills, such as listening, speaking and reading 


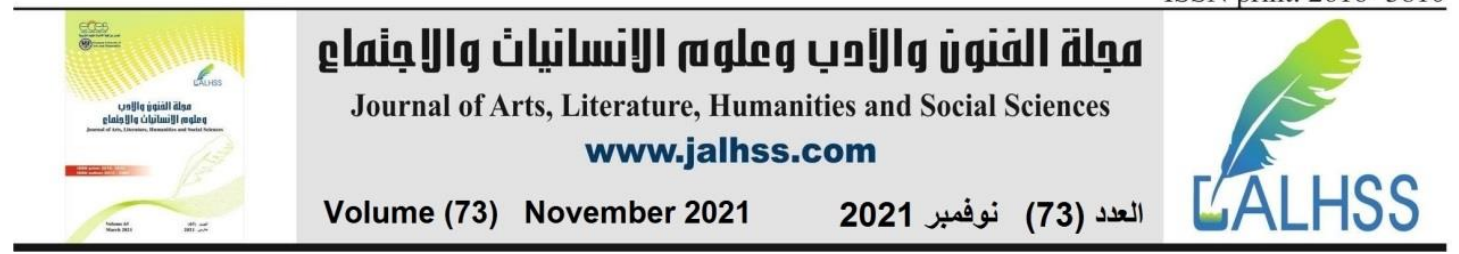

(Trueswell\&Tanenhaus, 1994).Thus, students could develop awareness of English word stress to acquire a better pronunciation of English. In addition, knowledge of phonological cues of grammatical class cold help nonnative learners of English succeed in language comprehension as they assign word stress appropriately based on their word class (Johnson \& Newport, 1989).

\section{Conclusion}

Contrastive analysis may have proven to be useful in predicting problematic areas concerning stress assignment. This study has explored the difficulties Saudi ESL learners encounter in English pronunciation. It experimented English word stress pronunciation and showed how prosodic transfer of Arabic could trigger such errors. Although stress patterns are responsible for most of the rhythmic structure, words stress rules of English and Arabic are quite different. In SA, stress is dependent on syllable quantity and therefore could be predictable. On the other hand, English word stress is sensitive to interrelated factors including moraic structure, lexical effects, syntactic category, whether the word is monomorphemic or polymorphemic (Oldin, 1989). This fact could increase the perplexity of foreign learners of English.Results reveal of negative transfer occurred in English words following syllable structure of SA. Saudi learners of English tended to misplace stress and use the strong-weak pattern in disyllable words and weak-strong pattern in compound words. The rule that subjects used is precisely that which assigns stress to SA words. This could be a result of negative transfer of Arabic stress rules as in Arabic stress falls on the first syllable in disyllable words, and on the second syllable in compound words. ESL learners found it difficult to identify the stress pattern of disyllabic English words. This inaccurate identification of stress patterns along with the fact that phonological cues to grammatical class related to phonemic distinctions are not present in the students' native language could be a trigger forthe insensitivity to English noun-verb stress difference. Moreover, students tended to change the vowel quality from weak to strong in order to apply the strong-weak pattern and change vowel quality from strong to weak to apply the weak-strong pattern most of the time. This means that even though students were aware that strong syllables receive stress, they tended to change the vowel quality in order to shift primary stress. In word-class pairs, verbs were classified more accurately than nouns among ESL speakers. Students seemed to have difficulty with the correlation between grammatical class and lexical stress in English. Most errors occurred with the trochaic pattern in disyllabic English nouns, whereas students make less errors in the iambic pattern in disyllabic verbs. Vowel change was triggered by misplacement of stress on all word-class pair categories. However, it occurred more frequently with disyllabic English verbs. From this study, it could be said that more instruction is not useful to overcome the influence of mother tongue language with respect to prosodic structures. Only exposure to English in real life context may be effective in that regard. It has been stated by Kelly(1992) that Phonological cues to grammatical class are language-specific, probabilistic and embedded in a background of other linguistic patterns. This, could justify the insensitivity of the existence of English suprasegmental features,such as word stress, 


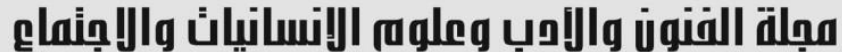 \\ Journal of Arts, Literature, Humanities and Social Sciences www.jalhss.com \\ Volume (73) November 2021 \\ العدد (73) نوفمبر 2021}

and as a result, errors occur. Consequently, subtle and arbitrary correlations should be implicitly learned (Gallistel, 1990). All in all, the results confirm earlier findings of (Ghazali 1973) and show the importance of mastering English rhythmic structures for intelligibility. Because English stress plays a important role in comprehensibility, it deserves much attention in English classes. Therefore, communicative methods of pronunciation skills should be integrated with other skills such as listening and speaking.

\section{References}

1. Altmann, H. (2006). The Perception of Second Language Stress: A Crosslinguistic Experimental Study. Delaware: University of Delaware.

2. Archibald, J. (1992). The Acquisition of English Stress by Speakers on Nonaccentual Languages: lexical Storage Versus Computation of Stress. Oxford: Oxford University Press.

3. Bahrick, H. \&Brger, S. (1994). Fifty Year of Language Dominance in Bilingual Hispanic Immigrants. Oxford: Basil Blackwell.

4. Betti, M. \&Ulaiwi,W. (2018). A dictionary of Linguistics and Literature. Beirut: :Lebanon Library.

5. Bian, F. (2013). psychology and Language.Beijing: Forign Language Teaching and Research Press.

6. Clak, J. \&Yallop, C. (1990). An Introduction to Phonetics and Phonology. Amsterdam: John Benjamin Publishing Company.

7. Choa, Y. (1968). A Grammar of Spoken Chinese. Berkeley: University of California Press.

8. Chen, J. (2008). Spoken Chinese. Beijing: Beijing Press.

9. Coniam, D. (2002). Mandarin Chinese. The Hague: Mouton.

10. Cook, V. (1996). Second Language Learning and Language Teaching. London: Arnold.

11. Ellis, R.(1994). The Study of Second Language Acquisition. Oxford: Oxford University Press.

12. Fry, D. (1958). Language and Speech. Cambridge: Cambridge University Press.

13. Gallistel, C. (1990). The organization of Learning. Cambridge: Cambridge University Press.

14. Garlson, R. Elenius, K. Grantorm, B. \&Hunnicutt, S. (1985). Contrastive analysis and Interlangauge. Shandong: Shandong University Press.

15. Ghazali, S. (1973).Contrastive Analysis of English and Arabic. Cambridge: Cambridge University Press.

16. Gleitman, L. (1990). Psychology. New York: Norton.

17. Gui, C. (1978). A Comparison Of Chinese and English Sound System. Harlow: Longman.

18. Guion, S.(2003). Knowledge of English Stress in Second Language Learners. Shanghai: Shanghai Foreign Language Education Press. 


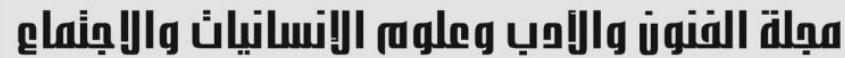 \\ Journal of Arts, Literature, Humanities and Social Sciences www.jalhss.com}

Volume (73) November 2021

العدد (73) نوفمبر 2021

19. Johnson, J. \& Newport, E. (1989). Critical Period Effects in Second Language Learning: The Influence of Maturational Sate on the Acquisition of English as a Second Language. New York: Norton.

20. Kelly, M. (1992). Using Sound to Solve Syntactic Problems: The Role of Phonology in Grammatical Category Assignment. New York: Oxford University Press.

21. Kelly, M.\& Martin, S. (1994). Domain-General Abilities Applied to DomainSpecific Tasks. Oxford: Basil Blackwell.

22. Kenworthey, J. (1987). Teaching English Pronunciation. Harlow: Longman.

23. Ladefoged, P. (1982). A Course in Phonetics. Boston: Thomson Wadsworth.

24. Levy, Y. (1983). It's Frogs All the Way Down. New York: Cambridge University Press.

25. Li, R. (1999). An Introduction to Language. Shandong: Shandong University Press.

26. Oldlin, T.(1989). Language Transfer: Course Linguistic Influence in Language Learning. Cambridge, UK: Cambridge University Press.

27. Roach, P. (2009). Phonetics. Cambridge: Cambridge University Press.

28. Sherman, D. (1975). Noun-Verb Stress Alternation: An Example of the lexical Diffusion of Sound Change in English. Oxford: Heinemann.

29. Swan, M.\& Smith, B. (1987). Learner English: A Teacher's Guide to Interference and Other Problems. Cambridge: Cambridge University Press.

30. Teschner, R.\& Whitley, M. (2004). Pronouncing English: An Update Overview. Shanghai: Shanghai Foreign Language Education Press.

31. Trueswell, J.\&Tanenhaus, M. (1994). Toward A Lexicalist Framework for Constraint-Based Syntactic Ambiguity Resolution. New York: Random House Inc.

32. Whitman, R.\& Jackson, K. (1972). The Unpredictability of Contrastive Analysis. Shanghai: Shanghai Foreign Language Education Press. 